\title{
A technique for quantifying intracellular free sodium ion using a microplate reader in combination with sodium-binding benzofuran isophthalate and probenecid in cultured neonatal rat cardiomyocytes
}

Daisuke Katoh", Kenichi Hongo, Keiichi Ito, Takuya Yoshino, Yosuke Kayama, Kimiaki Komukai, Makoto Kawai, Taro Date and Michihiro Yoshimura

\begin{abstract}
Background: Intracellular sodium $\left(\left[\mathrm{Na}^{+}\right]_{i}\right)$ kinetics are involved in cardiac diseases including ischemia, heart failure, and hypertrophy. Because $\left[\mathrm{Na}^{+}\right]_{i}$ plays a crucial role in modulating the electrical and contractile activity in the heart, quantifying $\left[\mathrm{Na}^{+}\right]_{i}$ is of great interest. Using fluorescent microscopy with sodium-binding benzofuran isophthalate (SBFI) is the most commonly used method for measuring $\left[\mathrm{Na}^{+}\right]_{\mathrm{i}}$. However, one limitation associated with this technique is that the test cannot simultaneously evaluate the effects of several types or various concentrations of compounds on $\left[\mathrm{Na}^{+}\right]_{\text {i }}$. Moreover, there are few reports on the long-term effects of compounds on $\left[\mathrm{Na}^{+}\right]_{\mathrm{i}}$ in cultured cells, although rapid changes in $\left[\mathrm{Na}^{+}\right]_{i}$ during a period of seconds or several minutes have been widely discussed.

Findings: We established a novel technique for quantifying $\left[\mathrm{Na}^{+}\right]_{i}$ in cultured neonatal rat cardiomyocytes attached to a 96-well plate using a microplate reader in combination with SBFI and probenecid. We showed that probenecid is indispensable for the accurate measurement because it prevents dye leakage from the cells. We further confirmed the reliability of this system by quantifying the effects of ouabain, which is known to transiently alter $\left[\mathrm{Na}^{+}\right]_{i}$. To illustrate the utility of the new method, we also examined the chronic effects of aldosterone on $\left[\mathrm{Na}^{+}\right]_{\mathrm{i}}$ in cultured cardiomyocytes.

Conclusions: Our technique can rapidly measure $\left[\mathrm{Na}^{+}\right]_{i}$ with accuracy and sensitivity comparable to the traditional microscopy based method. The results demonstrated that this 96-well plate based measurement has merits, especially for screening test of compounds regulating $\left[\mathrm{Na}^{+}\right]_{i}$, and is useful to elucidate the mechanisms and consequences of altered $\left[\mathrm{Na}^{+}\right]_{i}$ handling in cardiomyocytes.
\end{abstract}

Keywords: Intracellular sodium, Cardiomyocyte, SBFI, Probenecid, Microplate reader

\footnotetext{
* Correspondence: dkato@jikei.ac.jp

Division of Cardiology, Department of Internal Medicine, The Jikei University

School of Medicine, Tokyo 105-8461, Japan
} 


\section{Findings \\ Background}

The sodium ion $\left(\mathrm{Na}^{+}\right)$is the main determinant of the body fluid distribution, and transsarcolemmal $\mathrm{Na}^{+}$gradient is a key regulator of the various intracellular ions and metabolites. In the heart, the concentration of free intracellular $\mathrm{Na}^{+}\left(\left[\mathrm{Na}^{+}\right]_{\mathrm{i}}\right)$ has been shown to increase in the presence of cardiac diseases including ischemia, heart failure, and hypertrophy [1-5]. Because $\left[\mathrm{Na}^{+}\right]_{\mathrm{i}}$ is important in modulating the electrical and contractile activity, quantifying $\left[\mathrm{Na}^{+}\right]_{i}$ is of great interest. Therefore, several techniques for measuring $\left[\mathrm{Na}^{+}\right]_{\mathrm{i}}$ have been established to clarify the mechanisms and consequences of altered $\left[\mathrm{Na}^{+}\right]_{\mathrm{i}}$ regulation, and the standard procedure currently used for measuring $\left[\mathrm{Na}^{+}\right]_{\mathrm{i}}$ in a single cell is a fluorescent microscopy-based method [6-10]. Sodiumbinding benzofuran isophthalate (SBFI), the most widely used $\mathrm{Na}^{+}$-sensitive fluorescent indicator provides spatial and temporal resolution of $\left[\mathrm{Na}^{+}\right]_{i}$ with sufficient selectivity in the presence of physiological concentrations of other ions [11]. The ratiometric measurement with SBFI permits us to cancel out variable dye concentrations in the cells and shares the same filter equipment used for the $\mathrm{Ca}^{2+}$ indicator, Fura-2. Although the use of microscopy and ratio imaging in combination with SBFI has some merits, including the fact that it requires a minimal number of cells, permits the discrimination against dye leaked out of the cells, and provides the ability to see indicator compartmentalization [6], this technique requires a fluorescence microscope equipment to switch between filters. Furthermore, it is difficult to test the effects of several types of compounds and/or compounds at several concentrations simultaneously. On the other hand, a method using a cell suspension loaded with fluorescent indicator in a cuvette recorded by a spectrophotometer has been reported, but it might not be adequate for living adherent cells. Moreover, when one measures $\left[\mathrm{Na}^{+}\right]_{\mathrm{i}}$ in cells using a closed culture space without a perfusion chamber system to wash out the dye leaked from the cells, this leaked dye reduces the accuracy of the measurements of $\left[\mathrm{Na}^{+}\right]_{\mathrm{i}}[6]$.

Microplate readers with a 96-well format have been widely used in combination with various types of cellbased applications, including measuring the fluorescence intensity, because it employs a standardized rapid protocol for screening and examining multiple cell types and compounds, while requiring small amounts of materials. A method for measuring $\left[\mathrm{Ca}^{2+}\right]_{\mathrm{i}}$ in adherent cells attached to a 96-well microtiter plate using a microplate reader has been reported previously [12]. However, to our knowledge, no microplate reader-based method has previously been applied to measure $\left[\mathrm{Na}^{+}\right]_{\mathrm{i}}$ in cardiomyocytes in combination with SBFI. Moreover, there are few reports on the long-term effects of compounds on $\left[\mathrm{Na}^{+}\right]_{\mathrm{i}}$ in cultured cells, although rapid changes in $\left[\mathrm{Na}^{+}\right]_{\mathrm{i}}$ during a period of seconds or several minutes have been widely discussed. In comparison with adult cardiomyocytes, neonatal cells have the advantage of being easily cultured and having a longer viability. Therefore, we applied cultured neonatal rat ventricular cardiomyocytes (NRVM) in this system to examine the chronic effects of compounds on $\left[\mathrm{Na}^{+}\right]_{\mathrm{i}}$.

The aim of this study was to investigate a new method to measure $\left[\mathrm{Na}^{+}\right]_{\mathrm{i}}$ in NRVM attached to a 96-well microtiter plate using a microplate reader and to confirm the rational in vivo calibration method for SBFI in this system. We also investigated the effects of probenecid against dye leakage out of the cells. To confirm the reliability of this technique, the rapid effects of the $\mathrm{Na}^{+} / \mathrm{K}^{+}$ ATPase inhibitor, ouabain, on $\left[\mathrm{Na}^{+}\right]_{i}$ were evaluated. We further examined the chronic effects of aldosterone on $\left[\mathrm{Na}^{+}\right]_{\mathrm{i}}$ in NRVM to illustrate the utility of the new method.

\section{Results and discussion \\ Probenecid prevents the leakage of SBFI from cardiomyocytes}

As SBFI-AM hydrolyzes, the $340 / 380 \mathrm{~nm}$ excitation ratio gradually increases [6]. In our preliminary experiment, the fluorescence intensity continued to gradually increase during the measurements, even after the 60-minute period that had been previously reported to allow for complete hydrolysis [6]. Di Virgilio, et al. reported that the consequences of dye (Fura-2) leakage were relevant for experiments in closed cuvettes, because secreted dye can account for a considerable percentage of the total fluorescence signal [13-15]. Because each well of the 96-well plate that we used in our experiment was also a closed space, the gradual increase of fluorescence intensity after recording for a 60-minute period, at which time the completion of hydrolysis was expected [6], was speculated to be the result of dye leakage. Probenecid, an organic anion transport blocker, has been reported to prevent Fura-2 leakage from cells, and this effect has also been reported for SBFI used to measure $\left[\mathrm{Na}^{+}\right]_{\mathrm{i}}[16]$. Cao, et al. reported the value of $\left[\mathrm{Na}^{+}\right]_{\mathrm{i}}$ in neocortical neurons, and demonstrated that several compounds induced changes in $\left[\mathrm{Na}^{+}\right]_{\mathrm{i}}$ using a microplate reader with a 96-well format [17]. However, they did not use probenecid in their experiments. They might have been able to successfully measure $\left[\mathrm{Na}^{+}\right]_{\mathrm{i}}$ in neocortical neurons without taking into account the dye leakage, because the significance of dye leakage from the cells depends on the cell line.

To determine whether probenecid prevents dye leakage from cardiomyocytes in our 96-well microplate-based experiment, we compared the fluorescence ratio of SBFI in the cells incubated with the recording medium in the presence and absence of $1 \mathrm{mM}$ probenecid. Because a 

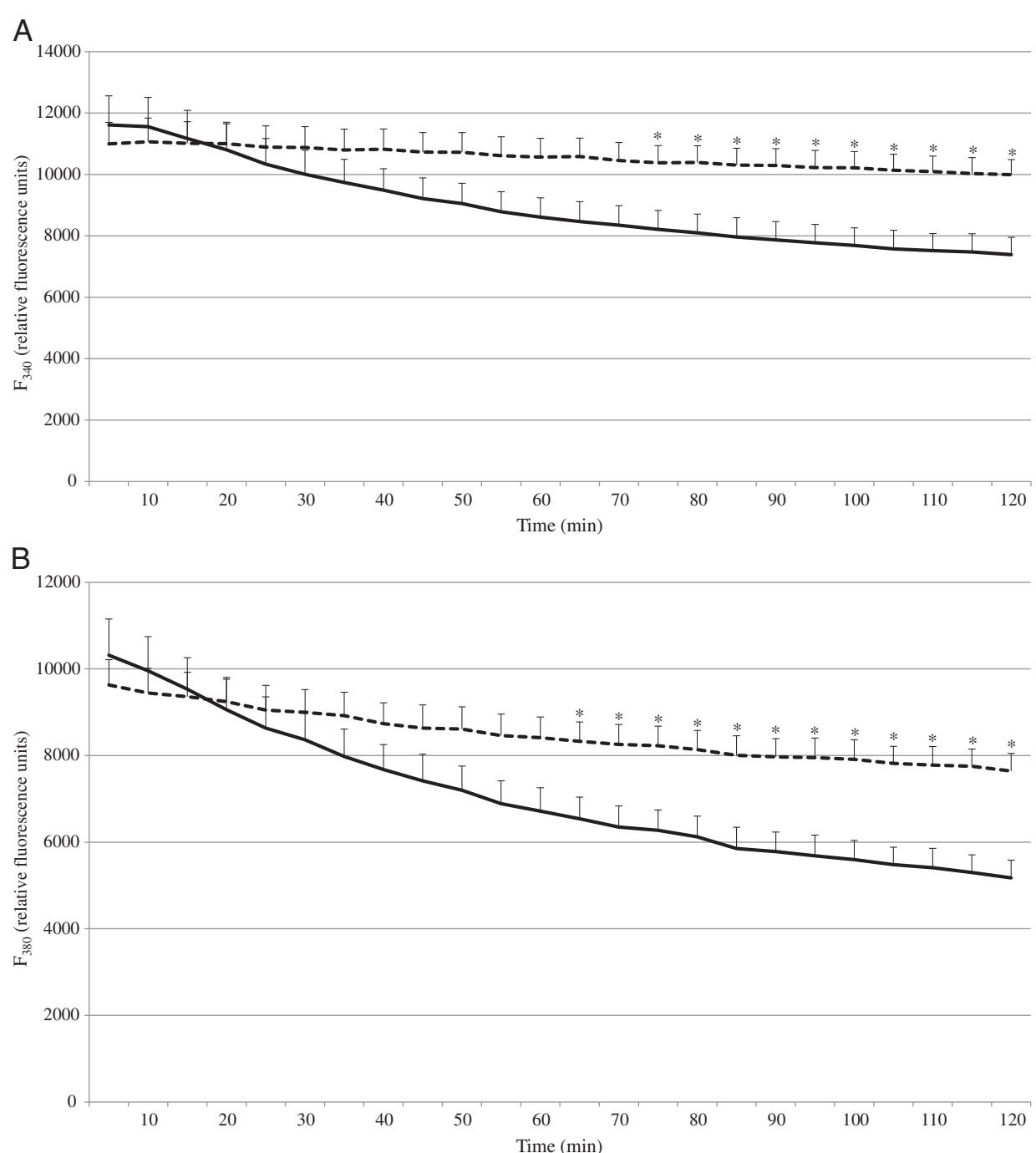

C

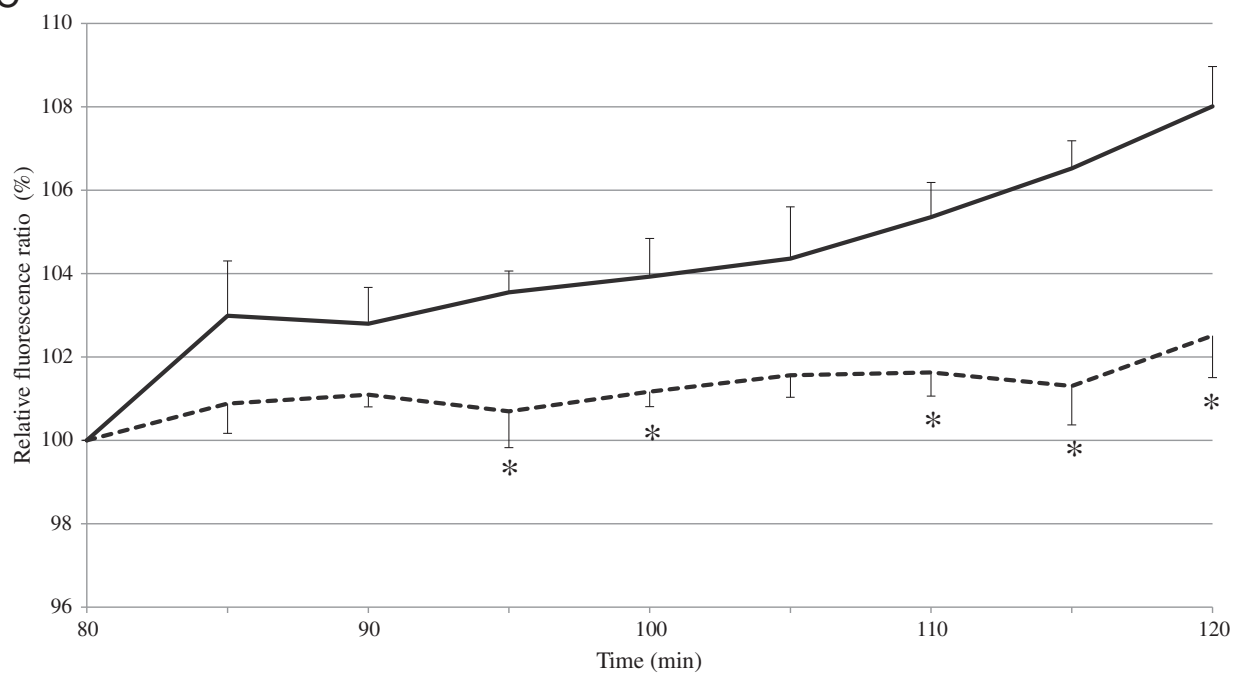

Figure 1 (See legend on next page.) 
(See figure on previous page.)

Figure 1 Probenecid inhibits SBFI leakage from neonatal rat cardiomyocytes. Adherent cardiomyocytes on a 96-well microplate were loaded with $5 \mathrm{MM}$ SBFI-AM for 90 min at room temperature. Cells were washed twice and incubated in Tyrode solution in the presence or absence of $1 \mathrm{mM}$ probenecid. The fluorescence intensity was measured every $5 \mathrm{~min}$. (A) The time course of the background-subtracted SBFI fluorescence intensity at $340 \mathrm{~nm}\left(\mathrm{~F}_{340}\right)$. (B) The time course of the background-subtracted SBFI fluorescence intensity at $380 \mathrm{~nm}\left(F_{380}\right)$. (C) The relative SBFI fluorescence ratio $\left(F_{340} / F_{380}\right)$, with the ratio at 80 min in each group considered to be $100 \%$. Solid lines, without probenecid; dashed lines, with probenecid. ${ }^{*} P<0.05$ vs cells treated without probenecid. The data are the means \pm SE from four experiments.

stable SBFI fluorescence ratio was obtained after approximately $80 \mathrm{~min}$ of recording with $1 \mathrm{mM}$ probenecid in the preliminary experiment, the relative fluorescence ratio compared to that at $80 \mathrm{~min}$ was estimated. Figures $1 \mathrm{~A}$ and $1 \mathrm{~B}$ clearly show the inhibitory effect of probenecid on the dye leakage from cardiomyocytes. A stable fluorescence ratio was obtained for at least $30 \mathrm{~min}$ after $80 \mathrm{~min}$ of recording in the presence of probenecid, while the ratio continued to increase in the wells without probenecid (solid line in Figure 1C. At 120 min recording, there was an estimated 8\% increase in the SBFI ratio, indicating an approximately 8-10 mM increase in $\left.\left[\mathrm{Na}^{+}\right]_{\mathrm{i}}\right)$. This result indicates that probenecid is essential to prevent the overestimation of $\left[\mathrm{Na}^{+}\right]_{i}$ caused by dye leakage. The concentrations of probenecid and time needed for treatment to inhibit dye leakage vary among different types of cells [13-15]. For our present method, probenecid effectively blocked SBFI efflux at a concentration of $1 \mathrm{mM}$, and was added only during the recording period after SBFI had been loaded into the cells. Therefore, in further experiments, we measured $\left[\mathrm{Na}^{+}\right]_{\mathrm{i}}$ in NRVM in Tyrode solution in the presence of $1 \mathrm{mM}$ of probenecid. Several reports have suggested that probenecid can lead to unwanted effects in cells. In particular, probenecid has been reported to reduce the rise in $\left[\mathrm{Ca}^{2+}\right]_{\mathrm{i}}$ induced by depolarization of the plasma membrane or by a receptor-directed agonist, such as bradykinin [14]. Although this may not affect $\left[\mathrm{Na}^{+}\right]_{\mathrm{i}}$ itself, attention is needed for the function of cells when using this agent for a long time.

\section{Measurement of $\left[\mathrm{Na}^{+}\right]_{\mathrm{i}}$ and intracellular SBFI calibration in NRVM}

Figure 2 shows a typical in vivo calibration experiment for SBFI in NRVM. Between 0 and $20 \mathrm{mM}\left[\mathrm{Na}^{+}\right]_{i}$, the SBFI fluorescence ratio $(340 / 380 \mathrm{~nm})$ showed a linear relationship with $\left[\mathrm{Na}^{+}\right]_{\mathrm{i}}$ (coefficient correlation $\left(\mathrm{R}^{2}\right)$ of 0.995 , with a slope of 0.14 ratio units per $10 \mathrm{mM}$ change in $\left.\left[\mathrm{Na}^{+}\right]_{\mathrm{i}}\right)$. The value of $\left[\mathrm{Na}^{+}\right]_{\mathrm{i}}$ in NRVM calculated using this method was $7.5 \pm 0.4 \mathrm{mM}(\mathrm{n}=24)$, which is similar to the value in neonatal cardiomyocytes $[18,19]$ and adult cells [9,20-22] measured by microscopy or a spectrophotometer, which ranged from 5 to $13 \mathrm{mM}$. These results suggest that our method has sensitivity comparable to the microscopy-based method. The value of $\left[\mathrm{Na}^{+}\right]_{\mathrm{i}}$ in myocytes depends on the ionic strength, $\mathrm{pH}$, and the composition of the solutions used during the isolation of the myocytes $[6,23,24]$. In addition, the $\left[\mathrm{Na}^{+}\right]_{\mathrm{i}}$ levels in freshly prepared and cultured cells have been reported to be different for other cell lines [25]. Therefore, the protocol used needs to be carefully understood to ensure that an accurate comparison can be made of the absolute value of $\left[\mathrm{Na}^{+}\right]_{\mathrm{i}}$. Dye compartmentalization has been reported when $\mathrm{SBFI}$ is loaded at physiological temperature $\left(37^{\circ} \mathrm{C}\right)$. However, this could be reduced by loading SBFI at room temperature [26,27]. In fact, the fraction of SBFI compartmentalized has been reported to range from 10 to $50 \%$ $[7,8,10]$, and it is still uncertain even when it is recorded by microscopy, because the loaded dye concentration and loading time have varied among experiments. The disadvantages associated with population-averaged protocols using a plate reader and multiple cells, which thus meant that we could not directly detect indicator compartmentalization in the cells in each experiment are considered to be negligible, due to the fact that the changes in the fluorescence ratio are considered to mainly reflect the changes in the cytoplasmic $\left[\mathrm{Na}^{+}\right]$levels [6-8].

\section{Transient effects of ouabain on $\left[\mathrm{Na}^{+}\right]_{i}$ in cardiomyocytes}

Ouabain is a specific $\mathrm{Na}^{+} / \mathrm{K}^{+}$pump inhibitor that has been widely used for the treatment of patients with heart failure and atrial fibrillation. Ouabain is known to transiently alter $\left[\mathrm{Na}^{+}\right]_{\mathrm{i}}$ in cardiomyocytes. To confirm the reliability of our technique, we examined the effects of ouabain at concentrations of $100 \mu \mathrm{M}$ and $200 \mu \mathrm{M}$ on $\left[\mathrm{Na}^{+}\right]_{\mathrm{i}}$ in NRVM. During the application of ouabain, $\left[\mathrm{Na}^{+}\right]_{\mathrm{i}}$ increased significantly in a dose-dependent manner (Figure 3 ). The mean value of $\left[\mathrm{Na}^{+}\right]_{\mathrm{i}}$ at $20 \mathrm{~min}$ in the cells treated with vehicle, $100 \mu \mathrm{M}$ and $200 \mu \mathrm{M}$ ouabain was $9.0 \pm 0.4 \mathrm{mM}$, $11.4 \pm 0.6 \mathrm{mM}$ and $15.2 \pm 1.0 \mathrm{mM}$, respectively $(\mathrm{n}=13)$. This result is comparable to the results reported using ouabain or another specific $\mathrm{Na}^{+} / \mathrm{K}^{+}$pump inhibitor, strophanthidin, which were measured by fluorescent microscopy or a spectrophotometer $[7,9,19]$, suggesting that our present technique detects the changes in $\left[\mathrm{Na}^{+}\right]_{i}$ induced by agents with accuracy comparable to the traditional microscopy-based method.

\section{The long-term effects of aldosterone on $\left[\mathrm{Na}^{+}\right]_{i}$ in cardiomyocytes}

We and others have recently reported that aldosterone induces $\left[\mathrm{Na}^{+}\right]_{\mathrm{i}}$ elevation in cultured cardiomyocytes, and that this effect was rapid, non-genomic, and occurred in a mineralocorticoid receptor-independent fashion [28,29]. 


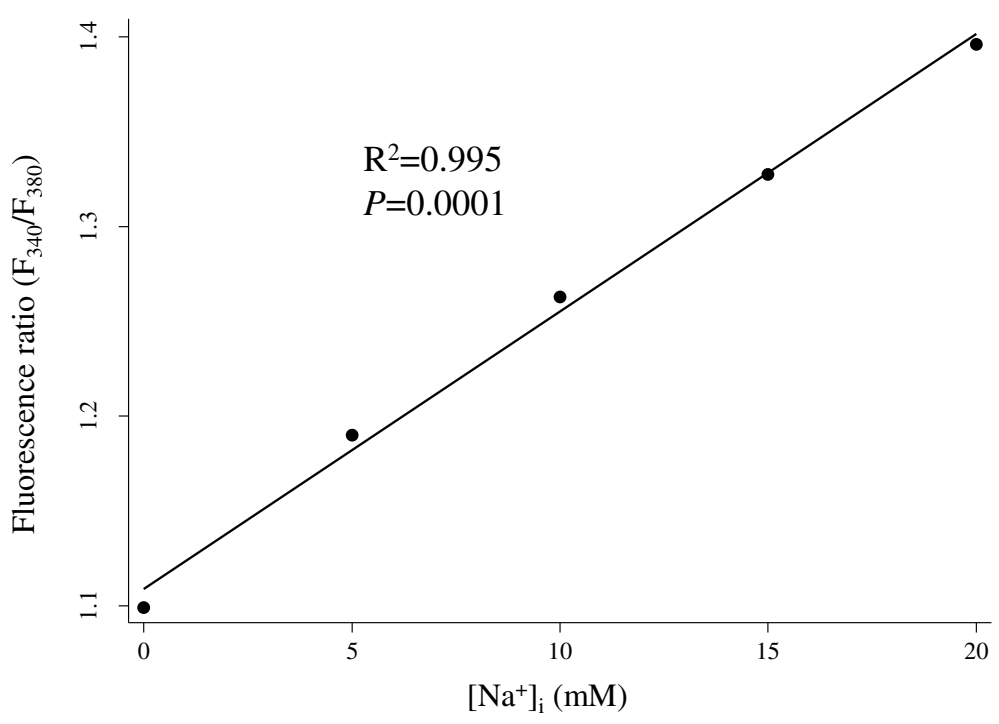

Figure 2 In vivo calibration of SBFI. The in vivo calibration of SBFI was accomplished by exposing the myocytes to various extracellular [Na $\left.{ }^{+}\right]$. Between 0 and $20 \mathrm{mM}\left[\mathrm{Na}^{+}\right]_{\mathrm{i}}$, the SBFI fluorescence ratio $\left(F_{340} / F_{380}\right)$ showed a linear relationship with $\left[\mathrm{Na}^{+}\right]_{\mathrm{i}}$ (coefficient correlation $\left.\left(R^{2}\right)=0.995, P=0.0001\right)$.

Although there was a previous report that aldosterone activated $\mathrm{Na}^{+} / \mathrm{H}^{+}$exchange in cardiomyocytes [30], the longterm effect of aldosterone on the estimated value of $\left[\mathrm{Na}^{+}\right]_{i}$ in cardiomyocytes is still unknown. To clarify this, we measured $\left[\mathrm{Na}^{+}\right]_{\mathrm{i}}$ in NRVM after treatment with vehicle or aldosterone at a concentration of $0.1 \mathrm{nM}$ to $100 \mathrm{nM}$ for $24 \mathrm{~h}$ using the new method. The mean value of $\left[\mathrm{Na}^{+}\right]_{\mathrm{i}}$ in cells treated with $100 \mathrm{nM}$ aldosterone was significantly higher than that of cells treated with vehicle $(9.1 \pm 0.5 \mathrm{mM}$ vs 6.7 $\pm 0.4 \mathrm{mM}, \mathrm{n}=11, P<0.01$ ), although a lower concentration of aldosterone did not affect $\left[\mathrm{Na}^{+}\right]_{\mathrm{i}}$ (Figure 4). This result indicates that chronic aldosterone exposure alters $\left[\mathrm{Na}^{+}\right]_{\mathrm{i}}$ handling in cardiomyocytes, which might have (patho) physiological effects in the heart.
Most of the previous studies about $\left[\mathrm{Na}^{+}\right]_{\mathrm{i}}$ in the heart were focused on the rapid effects of agents. However, altered $\left[\mathrm{Na}^{+}\right]_{i}$ handling under pathological conditions, including heart failure and cardiac hypertrophy, is a continuous phenomenon. In this context, using NRVM and investigating the change in $\left[\mathrm{Na}^{+}\right]_{\mathrm{i}}$ after long-term treatment with various compounds may be helpful for understanding the mechanisms and consequences of $\left[\mathrm{Na}^{+}\right]_{\mathrm{i}}$ handling in the heart.

\section{Conclusions}

The results of this study indicate that using a microplate reader and a ratiometric measurement of SBFI used in combination with probenecid provides accurate values

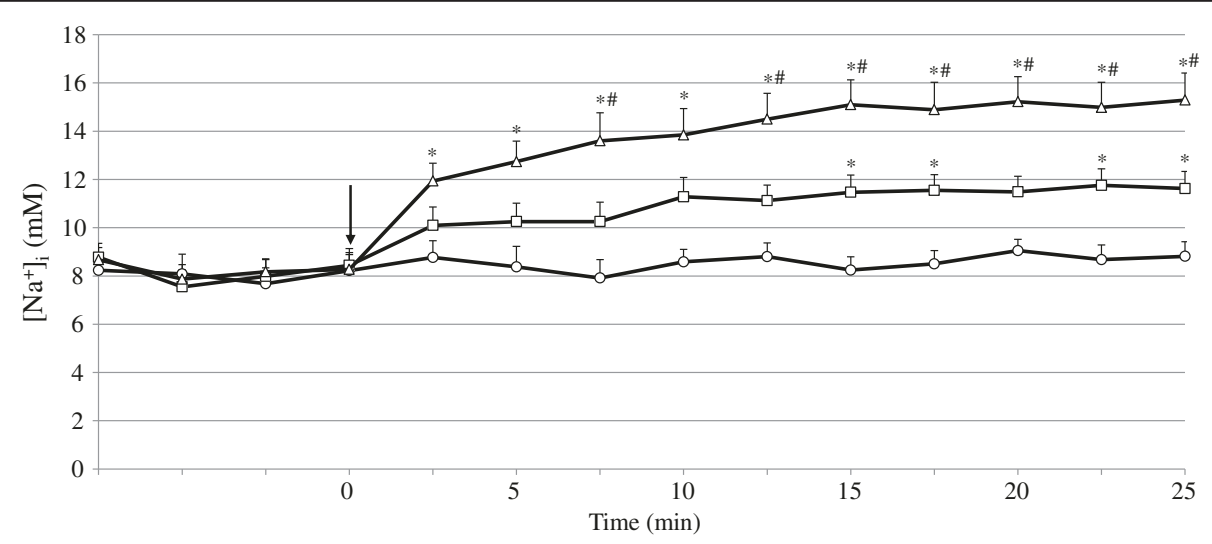

Figure 3 Effects of ouabain on $\left[\mathrm{Na}^{+}\right]_{i}$ in cardiomyocytes. The time-dependent changes in $\left[\mathrm{Na}^{+}\right]_{i}$ during the treatment with vehicle (open circle), $100 \mu \mathrm{M}$ ouabain (open square) and $200 \mu \mathrm{M}$ ouabain (open triangle). The data are the means \pm SE from 13 experiments. ${ }^{*} P<0.05$ vs vehicle, $\# P<0.05$ vs $100 \mu \mathrm{M}$ ouabain. The arrow indicates the application of compounds. 


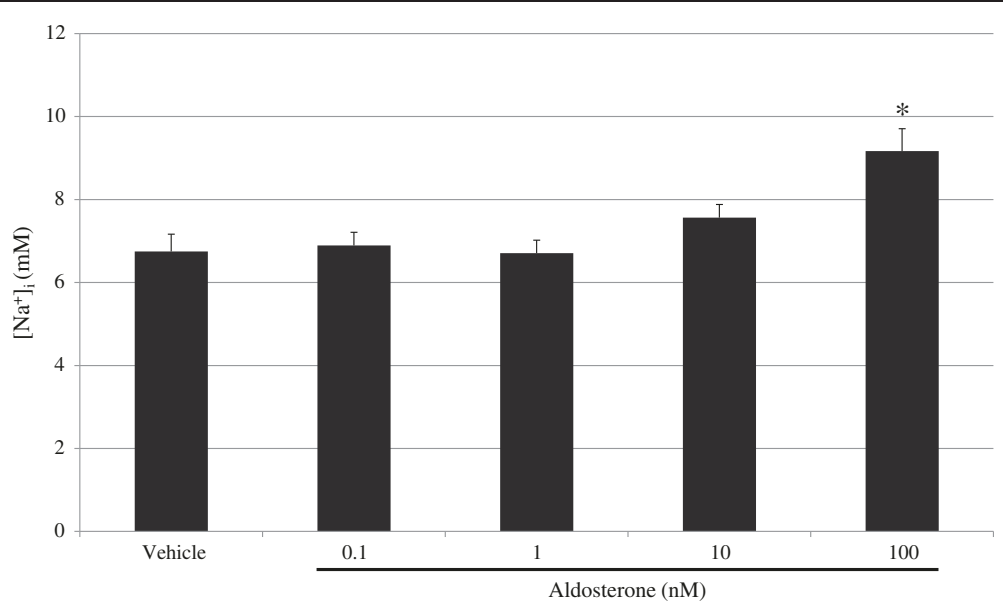

Figure 4 The long-term effects of aldosterone on $\left[\mathrm{Na}^{+}\right]_{i}$ in cardiomyocytes. Cardiomyocytes were treated with vehicle or aldosterone at a concentration of $0.1 \mathrm{nM}$ to $100 \mathrm{nM}$ for $24 \mathrm{~h}$. The data are the means \pm SE from 11 experiments. ${ }^{*} P<0.01$ vs vehicle.

for $\left[\mathrm{Na}^{+}\right]_{\mathrm{i}}$ in NRVM attached to 96-well plates. This method has merits in that it allows for the changes in $\left[\mathrm{Na}^{+}\right]_{\mathrm{i}}$ in cultured cells treated with several types or concentration of agents to be measured simultaneously, and provides a more thorough investigation of the long-term effects of agents. In addition, the present method can be applied to measure $\left[\mathrm{Na}^{+}\right]_{i}$ in other types of adherent cells with some modification of the concentration of probenecid and length of treatment.

\section{Methods}

\section{Preparation of cardiomyocytes and cell culture}

All animal procedures conformed to the National Institutes of Health Guide for the Care and Use of Laboratory Animals and were approved by the Animal Research Committee of Jikei University. NRVM were isolated from one- to three-day-old Sprague-Dawley rats according to the manufacturer's protocol from Worthington Biochemical (Lakewood, NJ). Purified NRVM were plated at a density of $1 * 10^{5}$ cells/well in 96 well clear bottom plates in low-glucose (1000 mg/liter) DMEM (GIBCO) supplemented with $10 \%$ fetal bovine serum (GIBCO), $20 \mathrm{mM}$ HEPES and antibiotics (100 U/ml penicillin G and $100 \mu \mathrm{g} /$ $\mathrm{ml}$ streptomycin; Wako). The cells were allowed to attach at $37^{\circ} \mathrm{C}$ in a $5 \% \mathrm{CO}_{2}$ atmosphere, and subconfluent myocyte monolayers were obtained after $48 \mathrm{~h}$. Sixteen hours before treatments with the indicated agents, the medium was replaced with DMEM supplemented with charcoalstripped FBS (GIBCO).

\section{Measurement of $\left[\mathrm{Na}^{+}\right]_{\mathrm{i}}$ in NRVM}

NRVM were loaded with $5 \mu \mathrm{M}$ SBFI-acetoxymethylester (AM) (Molecular Probes) dissolved in Tyrode solution (mM): $150 \mathrm{NaCl}, 5.4 \mathrm{KCl}, 1.2 \mathrm{MgCl}_{2}, 0.4 \mathrm{NaH}_{2} \mathrm{PO}_{4}, 10$ HEPES, 5 glucose, and $1 \mathrm{CaCl}_{2}(\mathrm{pH}$ 7.4) for $90 \mathrm{~min}$ at room temperature in the presence of the non-ionic surfactant, Pluronic F-127 (0.05\% w/v) [9,20]. After washing out the external dye twice with Tyrode solution, leaving a final volume of $200 \mu \mathrm{l}$ in each well, the fluorescence intensity was measured by an Infinite 200 PRO microplate reader (TECAN) at room temperature. Dual excitation measurements at $340 \mathrm{~nm}$ and $380 \mathrm{~nm}$ were performed, and the emitted fluorescence was recorded at $510 \pm 12.5 \mathrm{~nm}$ by the fluorescence bottom reading mode. The completion of hydrolysis was judged by attainment of a stable $340 / 380 \mathrm{~nm}$ ratio. In the experiments using ouabain, after attainment of a stable fluorescence ratio, we replaced $50 \mu \mathrm{l}$ of medium in each well with $50 \mu \mathrm{l}$ of a ouabain-containing solution. The microplate reader can take measurements in each well of a plate within 90 seconds, and the fluorescence intensity was automatically recorded every 2.5-5 minutes. In each microplate, NRVM of the same preparation in 10 wells were prepared with Tyrode solution in the absence of SBFI to measure the background signals of NRVM and microplates. Mean fluorescence signals from the 10 SBFIunloaded wells at $340 \mathrm{~nm}$ and $380 \mathrm{~nm}$ were subtracted from the individual signals of SBFI-loaded wells at each wavelength. All of the experimental conditions, including in vivo calibrations, were performed in sextuplicate.

\section{In vivo calibration of SBFI}

The in vivo calibration of SBFI was accomplished, similar to the previous reports, by exposing the cardiomyocytes to various concentrations of extracellular $\left[\mathrm{Na}^{+}\right](0-20 \mathrm{mM})$ in the presence of $1 \mathrm{mg} / \mathrm{l}$ gramicidin $\mathrm{D}, 100 \mu \mathrm{M}$ strophanthidin, $2 \mathrm{mM}$ EGTA, and the $\mathrm{pH}$ was adjusted to 7.1 with Tris base $[9,20]$. Myocytes had been treated with gramicidin $\mathrm{D}$ to allow the free movement of $\mathrm{Na}^{+}, \mathrm{K}^{+}$, and $\mathrm{H}^{+}$, strophanthidin to inhibit the $\mathrm{Na}^{+} / \mathrm{K}^{+}$pump, and EGTA to increase the permeability of the cell membrane to $\mathrm{Na}^{+}[6,8,9]$. Using these agents, a stable equilibrium 
between the intracellular and the extracellular $\left[\mathrm{Na}^{+}\right]$was achieved. A linear fit of the calibration plots between 0 and $20 \mathrm{mM}\left[\mathrm{Na}^{+}\right]_{\mathrm{i}}$ was used to convert SBFI fluorescence ratios $(340 / 380 \mathrm{~nm})$ to values of $\left[\mathrm{Na}^{+}\right]_{\mathrm{i}}$. The calibration solutions were prepared by mixing two solutions of equal ionic strength. One solution contained $145 \mathrm{mM} \mathrm{Na}{ }^{+}$ (30 $\mathrm{mM} \mathrm{NaCl}, 115 \mathrm{mM}$ sodium gluconate) and no $\mathrm{K}^{+}$, while the other one had $145 \mathrm{mM} \mathrm{K}^{+}(30 \mathrm{mM} \mathrm{KCl}$, $115 \mathrm{mM}$ potassium gluconate) and no $\mathrm{Na}^{+}$. Under these calibration conditions, the effect of $\mathrm{K}^{+}$on SBFI is negligible in physiological $\left[\mathrm{Na}^{+}\right]_{\mathrm{i}}$ between 0 and $20 \mathrm{mM}$, although SBFI is known to be sensitive to $\mathrm{K}^{+}$[9]. A calibration was performed at the end of each experiment.

\section{Statistical analyses}

The data are expressed as the means \pm standard error for the indicated number of experiments. The statistical analyses were performed using Student's $t$ test and one way ANOVA, followed by Scheffe's test. Values of $P<0.05$ were considered to be significant.

\section{Competing interests}

The authors declare no competing interests.

\section{Authors' contributions}

DK, TY, KI performed experiments; DK, KH, KK, MK, TD and MY designed experiments; DK, KH, YK and MY wrote manuscript. All authors read and approved the final manuscript.

Received: 10 July 2013 Accepted: 18 December 2013

Published: 26 December 2013

\section{References}

1. Despa S, Islam MA, Weber CR, Pogwizd SM, Bers DM: Intracellular $\mathrm{Na}^{+}$ concentration is elevated in heart failure but $\mathrm{Na} / \mathrm{K}$ pump function is unchanged. Circulation 2002, 105:2543-2548.

2. Bers DM, Barry WH, Despa S: Intracellular $\mathrm{Na}^{+}$regulation in cardiac myocytes. Cardiovasc Res 2003, 57:897-912.

3. Pieske $B$, Houser $S R:\left[\mathrm{Na}^{+}\right]_{\mathrm{i}}$ handling in the failing human heart. Cardiovasc Res 2003, 57:874-886.

4. Pogwizd SM, Sipido KR, Verdonck F, Bers DM: Intracellular Na in animal models of hypertrophy and heart failure: contractile function and arrhythmogenesis. Cardiovasc Res 2003, 57:887-896.

5. Murphy E, Eisner DA: Regulation of intracellular and mitochondrial sodium in health and disease. Circ Res 2009, 104:292-303.

6. Harootunian AT, Kao JP, Eckert BK, Tsien RY: Fluorescence ratio imaging of cytosolic free $\mathrm{Na}^{+}$in individual fibroblasts and lymphocytes. J Biol Chem 1989, 264:19458-19467.

7. Satoh H, Hayashi H, Noda N, Terada H, Kobayashi A, Yamashita Y, Kawai T, Hirano M, Yamazaki N: Quantification of intracellular free sodium ions by using a new fluorescent indicator, sodium-binding benzofuran isophthalate in guinea pig myocytes. Biochem Biophys Res Commun 1991, 175:611-616.

8. Donoso P, Mill JG, O'Neill SC, Eisner DA: Fluorescence measurements of cytoplasmic and mitochondrial sodium concentration in rat ventricular myocytes. J Physiol 1992, 448:493-509.

9. Harrison SM, McCall E, Boyett MR: The relationship between contraction and intracellular sodium in rat and guinea-pig ventricular myocytes. J Physiol 1992, 449:517-550.

10. Borzak S, Reers M, Arruda J, Sharma VK, Sheu SS, Smith TW, Marsh JD: $\mathrm{Na}^{+}$ efflux mechanisms in ventricular myocytes: measurement of $\left[\mathrm{Na}^{+}\right]_{i}$ with $\mathrm{Na}^{+}$-binding benzofuran isophthalate. Am J Physiol 1992, 263:H866-H874.

11. Minta A, Tsien RY: Fluorescent indicators for cytosolic sodium. J Biol Chem 1989, 264:19449-19457.

12. Lin K, Sadee W, Quillan JM: Rapid measurements of intracellular calcium using a fluorescence plate reader. Biotechniques 1999, 26:318-322. 324-6.
13. Di Virgilio F, Fasolato C, Steinberg TH: Inhibitors of membrane transport system for organic anions block fura-2 excretion from PC12 and N2A cells. Biochem J 1988, 256:959-963.

14. Di Virgilio F, Steinberg TH, Swanson JA, Silverstein SC: Fura-2 secretion and sequestration in macrophages. A blocker of organic anion transport reveals that these processes occur via a membrane transport system for organic anions. J Immunol 1988, 140:915-920.

15. Di Virgilio F, Steinberg TH, Silverstein SC: Inhibition of Fura-2 sequestration and secretion with organic anion transport blockers. Cell Calcium 1990, 11:57-62.

16. Bosteels S, Matejovic P, Flameng W, Mubagwa K: Sodium influx via a non-selective pathway activated by the removal of extracellular divalent cations: possible role in the calcium paradox. Cardiovasc Res 1999, 43:417-425.

17. Cao Z, George J, Gerwick WH, Baden DG, Rainier JD, Murray TF: Influence of lipid-soluble gating modifier toxins on sodium influx in neocortical neurons. J Pharmacol Exp Ther 2008, 326:604-613.

18. Fang KM, Lee AS, Su MJ, Lin CL, Chien CL, Wu ML: Free fatty acids act as endogenous ionophores, resulting in $\mathrm{Na}^{+}$and $\mathrm{Ca}^{2+}$ influx and myocyte apoptosis. Cardiovasc Res 2008, 78:533-545.

19. Yamamoto K, Ikeda U, Seino Y, Tsuruya Y, Oguchi A, Okada K, Ishikawa S, Saito T, Kawakami K, Hara Y: Regulation of $\mathrm{Na}$, K-adenosine triphosphatase gene expression by sodium ions in cultured neonatal rat cardiocytes. J Clin Invest 1993, 92:1889-1895.

20. Despa S, Islam MA, Pogwizd SM, Bers DM: Intracellular $\left[\mathrm{Na}^{+}\right]$and $\mathrm{Na}+$ pump rate in rat and rabbit ventricular myocytes. J Physiol 2002, 539:133-143.

21. Hongo K, White $\mathrm{E}$, Le Guennec JY, Orchard CH: Changes in $\left[\mathrm{Ca}^{2+}\right]_{\mathrm{i}},\left[\mathrm{Na}^{+}\right]_{\mathrm{i}}$ and $\mathrm{Ca}^{2+}$ current in isolated rat ventricular myocytes following an increase in cell length. J Physiol 1996, 491:609-619.

22. Baartscheer A, Schumacher CA, Fiolet JW: Small changes of cytosolic sodium in rat ventricular myocytes measured with SBFI in emission ratio mode. J Mol Cell Cardiol 1997, 29:3375-3383.

23. Suleiman MS, Chapman RA: Interaction between intracellular levels of amino acids and sodium in isolated guinea-pig hearts during calcium depletion. J Physiol 1990, 430:72P.

24. Diarra A, Sheldon C, Church J: In situ calibration and $\left[\mathrm{H}^{+}\right]$sensitivity of the fluorescent $\mathrm{Na}^{+}$indicator SBFI. Am J Physiol Cell Physiol 2001, 280:C1623-C1633.

25. van der Bent V, Demole C, Johnson El, Rossier MF, Python CP, Vallotton MB, Capponi AM: Angiotensin-II induces changes in the cytosolic sodium concentration in bovine adrenal glomerulosa cells: involvement in the activation of aldosterone biosynthesis. Endocrinology 1993, 133:1213-1220.

26. Negulescu PA, Harootunian A, Tsien RY, Machen TE: Fluorescence measurements of cytosolic free Na concentration, influx and efflux in gastric cells. Cell Regul 1990, 1:259-268.

27. Wong MM, Foskett JK: Oscillations of cytosolic sodium during calcium oscillations in exocrine acinar cells. Science 1991, 254:1014-1016.

28. Yamamuro M, Yoshimura M, Nakayama M, Abe K, Shono M, Suzuki S, Sakamoto T, Saito Y, Nakao K, Yasue H, Ogawa H: Direct effects of aldosterone on cardiomyocytes in the presence of normal and elevated extracellular sodium. Endocrinology 2006, 147:1314-1321.

29. Matsui S, Satoh H, Kawashima H, Nagasaka S, Niu CF, Urushida T, Katoh H, Watanabe $\mathrm{Y}$, Hayashi $\mathrm{H}$ : Non-genomic effects of aldosterone on intracellular ion regulation and cell volume in rat ventricular myocytes. Can J Physiol Pharmacol 2007, 85:264-273.

30. Karmazyn M, Liu Q, Gan XT, Brix BJ, Fliegel L: Aldosterone increases NHE-1 expression and induces $\mathrm{NHE}-1$-dependent hypertrophy in neonatal rat ventricular myocytes. Hypertension 2003, 42:1171-1176.

\section{doi:10.1186/1756-0500-6-556}

Cite this article as: Katoh et al:: A technique for quantifying intracellular free sodium ion using a microplate reader in combination with sodium-binding benzofuran isophthalate and probenecid in cultured neonatal rat cardiomyocytes. BMC Research Notes 2013 6:556. 